\title{
Marine protection targets: an updated assessment of global progress
}

\author{
Lis a Boonzaier and Daniel Pauly
}

\begin{abstract}
Despite the considerable expansion in the number and extent of marine protected areas during the past century, coverage remains limited amid concerns that many marine protected areas are failing to meet their objectives. New estimates of global marine protected area, based on the database maintained by Sea Around Us, revealed a degree of progress towards protecting at least $10 \%$ of the global ocean by 2020 . It is estimated that $>6,000$ marine protected areas, covering c. $3.27 \%$ (12 million $\mathrm{km}^{2}$ ) of the oceans, had been designated by the end of 2013. However, protection is generally weak, with $\mathrm{c}$. one-sixth $\left(1.9\right.$ million $\left.\mathrm{km}^{2}\right)$ of the combined area designated as no-take areas (i.e. fishing and other extractive activities are prohibited). Additional large tracts of ocean will need to be protected to reach the $10 \%$ target, and we investigate hypothetical scenarios for such expansion. Such scenarios offer a one-dimensional measure of progress as they do not address aspects of other global targets, such as Aichi Target 11, which will help to ensure that marine protected areas meet their objectives and achieve conservation outcomes.
\end{abstract}

Keywords Aichi target 11, biodiversity, conservation target, global, international policy, marine protected area, no-take area

\section{Introduction}

$\mathrm{M}$ arine protected areas are one of many tools for protecting the marine environment, and a number of international targets have been set to encourage their establishment. In 2010, Parties to the Convention on Biological Diversity adopted the Aichi Targets, Target 11 of which commits participating countries to conserving at least $10 \%$ of coastal and marine areas by 2020 'through effectively and equitably managed, ecologically representative and well-connected systems of protected areas and other effective area-based conservation measures. . .integrated into the wider landscapes and seascapes' (CBD, 2010). More

LisA BoonZAiER* (Corresponding author) Save Our Seas Foundation, 28 Main Road, Kalk Bay, 7975, South Africa. E-mail lisa.boonzaier@gmail.com

Daniel Pauly Sea Around Us, University of British Columbia, Vancouver Canada

${ }^{*}$ Also at: Sea Around Us, University of British Columbia, Vancouver, Canada

Received 20 March 2015. Revision requested 21 May 2015.

Accepted 30 June 2015. First published online 26 October 2015. recently, participants at the 2014 World Parks Congress recommended that $30 \%$ of the ocean be protected from extractive activities (IUCN, 2014), an ambitious but nonbinding conservation target reinforcing the earlier recommendation of the 2003 World Parks Congress for $20-30 \%$ of the oceans to be no-take areas (IUCN, 2003).

Overall, progress towards meeting international targets has been slow and targets have not been met (Wood et al., 2008; Toropova et al., 2010; Wood, 2011; Veitch et al., 2012). Since the mid 2000 s there has been a dramatic increase in the protection of large areas of ocean, which could influence trends in the growth of protected areas. In $2014 \mathrm{New}$ Caledonia declared the $1,291,000 \mathrm{~km}^{2}$ Natural Park of the Coral Sea, and the USA expanded the Pacific Remote Islands Marine National Monument from 216,000 to $1,267,000 \mathrm{~km}^{2}$. The previous year Australia established the 990,000 $\mathrm{km}^{2}$ Coral Sea Commonwealth Marine Reserve, and South Africa legally designated the Prince Edward Islands Marine Protected Area, adding $180,000 \mathrm{~km}^{2}$ to global coverage. Other large marine protected areas are in the planning stages and are due to be designated in the near future (Table 1).

A comprehensive assessment of marine protected area coverage shows an increase to $2.3 \%$ of the global ocean in 2012 (Spalding et al., 2013), from $0.65 \%$ in 2006 (Wood et al., 2008). The area of protected ocean within Exclusive Economic Zones increased from 1.6\% (Wood et al., 2008) to 5.5\% (Spalding et al., 2013) during 2006-2012. However, significant expansion in marine protected area is required to reach the $10 \%$ coverage target of the Convention on Biological Diversity by 2020 .

The utility of global percentage targets has been questioned (e.g. Margules \& Pressey, 2000; Agardy et al., 2003; Wood, 2011; De Santo, 2013). Although designation of marine protected areas is not sufficient to ensure effective conservation, it is a first step, and protected area extent is a simple, comprehensible and quantifiable metric that has been chosen by the international community to encourage conservation action. The objectives of this research are to investigate the extent of designated marine protected areas by providing an updated estimate of global marine protected area, both total and no-take, and assessing the feasibility of protecting $10 \%$ of global marine areas by 2020 .

\section{Methods}

The methods used are largely based on those of Wood et al. (2008). 
TABLE 1 Large marine protected areas proposed for establishment within Exclusive Economic Zones (EEZ), with their location, size, contribution to global coverage, and description. The table does not present confirmed or prescriptive information about the proposed marine protected areas but outlines a possible scenario for future increase in coverage.

\begin{tabular}{|c|c|c|c|}
\hline Location & $\begin{array}{l}\text { Size } \\
\left(10^{3} \mathrm{~km}^{2}\right)\end{array}$ & $\begin{array}{l}\text { Contribution to } \\
\text { global coverage } \\
\left(10^{3} \mathrm{~km}^{2}\right)\end{array}$ & Description \\
\hline Ascension & 442 & 442 & EEZ, excluding inner fishing area ${ }^{1}$ \\
\hline Bermuda & 254 & 254 & EEZ, excluding inner fishing area ${ }^{2}$ \\
\hline Cook Islands & 1,065 & 1,065 & Almost half of $\mathrm{EEZ}^{3}$ \\
\hline Easter Island & 714 & 564 & $\begin{array}{l}\text { EEZ, excluding an inner fishing area proposed } \\
\text { to extend } 20-60 \mathrm{~km} \text { from shore }\end{array}$ \\
\hline French Polynesia & 700 & 700 & Waters around Marquesas Islands ${ }^{5}$ \\
\hline Kermadec Islands & 678 & 0 & $\begin{array}{l}\text { Entire EEZ already designated a benthic } \\
\text { protection area }^{6}\end{array}$ \\
\hline Palau & 604 & 604 & Entire $\mathrm{EEZ}^{7}$ \\
\hline Pitcairn Islands & 834 & 834 & $\begin{array}{l}\text { EEZ, excluding inner fishing area extending } \\
12 \mathrm{~nm}(22 \mathrm{~km}) \text { from shore }\end{array}$ \\
\hline $\begin{array}{l}\text { South Georgia \& the } \\
\text { South Sandwich Islands }\end{array}$ & 532 & 0 & $\begin{array}{l}\text { EEZ north of } 60^{\circ} \text { latitude, already an IUCN } \\
\text { category VI marine protected area }{ }^{9}\end{array}$ \\
\hline Total & 5,823 & 4,463 & \\
\hline
\end{tabular}

${ }^{1}$ Estimated marine area based on the inner fishing area extending to $5 \mathrm{~nm}(9 \mathrm{~km}$; RSPB, 2014)

${ }^{2}$ Estimated marine area based on the inner fishing area extending to $140 \mathrm{~nm}(259 \mathrm{~km})$, representing the midpoint of three marine protected area options presented by the Government of Bermuda (2013)

${ }^{3}$ MPA News (2012); Marae Moana (2015)

${ }^{4}$ Estimated marine area based on the inner fishing area extending to c. $45 \mathrm{~km}$, representing the midpoint of the proposed areas (The Pew Charitable Trusts, 2012)

${ }^{5}$ MPA News (2014b)

${ }^{6}$ The Pew Charitable Trusts (2015a)

${ }^{7}$ Marianas Variety (2015)

${ }^{8}$ At the time of submission of this article, budget had been allocated to this marine protected area; The Pew Charitable Trusts (2015b)

${ }^{9}$ A. Gammell, Global Ocean Legacy, The Pew Charitable Trusts, pers. comm.

\section{Database}

The global database of marine protected areas originally developed by Wood et al. (2008) and maintained by Sea Around Us (2015) was updated and expanded using a variety of data sources, including national inventories, other protected area databases, legislation, management plans, peer-reviewed and grey literature, and direct communication with local experts. Some 600 sites were deleted as non-qualifying marine protected areas (based on their not conforming to the two widely accepted definitions of marine protected areas below), $>700$ site details were updated and $>2,500$ records were added.

The criterion originally used for inclusion of marine protected areas in the database (Wood et al., 2008) was based on the 1999 IUCN definition: 'Any area of intertidal or subtidal terrain, together with its overlying water and associated flora, fauna, historical and cultural features, which has been reserved by law or other effective means to protect part or all of the enclosed environment' (Kelleher, 1999). This has since been superseded by a new definition: 'A clearly defined geographical space, recognized, dedicated and managed, through legal or other effective means, to achieve the long-term conservation of nature with associated ecosystem services and cultural values' (Dudley, 2008). This definition does not refer to the marine environment specifically. Whereas the updated definition was relied upon to differentiate between protected areas and areas declared for extractive uses (Dudley, 2008), the 1999 definition specifies the criterion for a marine rather than a terrestrial protected area. As per Wood et al. (2008), this definition was applied by reviewing whether the legal boundary of a site extended seawards of the mean high-water mark. Other criteria for inclusion in the database are outlined in Wood et al. (2008).

\section{Marine protected area coverage}

Global marine protected area was estimated based on all marine protected areas in the database up to the end of 2013, with the addition of the two large areas of ocean, each $>1$ million $\mathrm{km}^{2}$, protected during 2014. These are New Caledonia's Natural Park of the Coral Sea and the expanded area of the U.S. Pacific Remote Islands Marine National Monument, both established within Exclusive Economic Zones. Although the database does not include all marine protected areas established up to the end of 2014, ensuring inclusion of the largest ones was a priority as these represent a disproportionately large percentage of global coverage. 
Given the lack of spatial data for many marine protected areas in the database, coverage was calculated by summing their marine areas, with the exception of marine protected areas in Australia, the USA and the UK, which are known to have significant overlapping areas and have comprehensive spatial data available. UNESCO World Heritage sites, UNESCO Man and the Biosphere reserves, and Ramsar sites (wetlands of international importance) were excluded because of their near-complete overlap with nationally designated sites. This decision is in line with other global studies of marine protected areas (e.g. Wood et al., 2008; Toropova et al., 2010). When the marine area was unknown, the total area was prorated according to the median proportion of marine area (relative to total area) for those marine protected areas for which this quantity was known in that country. Thus it was assumed that marine protected areas within a country were similar in terms of their marine and terrestrial proportions. Marine protected areas for which there was no areal information (c. 5\%) were excluded from coverage statistics.

For Australia, the USA and the UK, all of which have large areas of overlapping marine protected area designations, alternative sources of comprehensive spatial information were used. For Australia, 2012 spatial data were downloaded from the Collaborative Australian Protected Areas Database and used without amendment. For the USA, spatial data current as of March 2013 were accessed from the National Oceanic and Atmospheric Administration's marine protected area inventory, and the following amendments were made to the dataset: (1) protected areas in the Great Lakes were excluded, and (2) temporally dynamic sites and those with sustainable production as their primary conservation focus were excluded as they do not fulfil the IUCN definition of a protected area, which stipulates that protected areas should be designated for the long term and have the primary objective of nature conservation (Day et al., 2012; NOAA, 2013). However, some U.S. sites that do not fulfil the IUCN definition remain in the database (i.e. fisheries management areas that offer limited protection). To calculate total marine protected area and its annual increase for Australia and the USA, all overlapping areas were removed using the Symmetrical Difference tool in $\operatorname{ArcGIS}$ v. 10.2 (ESRI, Redlands, USA) to avoid doublecounting. For the UK, data for annual, cumulative marine protected area coverage were taken from the UK Biodiversity Indicators in Your Pocket 2013 report (indicator $\mathrm{C}_{1}$ ) current to June 2013 (Defra \& JNCC, 2013). Although there was probably some overlap of marine protected areas in other countries, this was considered to be negligible relative to the total marine protected area.

\section{No-take coverage}

No-take marine protected areas or zones were considered to be 'marine areas in which the extraction of living and non-living resources is permanently prohibited, except as necessary for monitoring or research to evaluate effectiveness' (Jones, 2007). However, for most countries the definition used by national data sources for no-take coverage was relied upon, which potentially introduced inconsistencies with regard to this definition; for example, Papahānaumokuākea Marine National Monument is listed as a no-take area by the National Oceanic and Atmospheric Administration, although it allows some subsistence fishing by permit (NOAA, 2011).

For the USA and Australia the total no-take area was calculated using spatial datasets (as above) and their associated metadata. For the USA all marine protected areas designated as no take, no access and no impact in the National Oceanic and Atmospheric Administration's marine protected area inventory were included in calculations of no-take area. This criterion provides an approximate delineation between no-take and other marine protected areas as it includes some areas that allow limited extractive uses and excludes others with zoned no-take areas.

For Australia, IUCN management categories Ia, Ib and II were used as a proxy for the presence of no-take regulations. Although IUCN management categories have generally been applied inconsistently, Australia has implemented a national initiative to align its protected area designations with the IUCN management categories. Again, however, this does not provide a clear criterion. Although categories Ia, Ib and II are considered to be largely incompatible with extractive uses (except some traditional use in Ib and II protected areas), in practice IUCN management categories are applied according to management objectives, not management actions (Day et al., 2012); thus, there may be inconsistencies regarding allowable activities (Fitzsimons, 2011). Despite this uncertainty, using the IUCN management categories as a proxy for no-take area in Australia was considered the most suitable option. The only amendment was to exclude the 2012 Commonwealth marine protected areas (including the Coral Sea Marine Reserve, approximately half of which would have been no-take) from no-take area calculations, as the management plans for these sites have been scrapped and will be redrafted (MPA News, 2013, 2014a).

Information on no-take area was available for most marine protected areas (c. $67 \%$ ). An additional $1 \%$ of marine protected areas were known to be partly no-take, although the exact no-take area was unknown. The total marine area of these marine protected areas was prorated using the median proportion of no-take area (relative to total marine area) for those marine protected areas for which this quantity was known. Thus it was assumed that marine protected areas with some no-take area were similar in terms of the proportion of their area designated as no take. Marine protected areas for which there was no information about the extent of their no-take area were excluded from calculations of no-take coverage. Although the expanded Pacific Remote 
Islands Marine National Monument has been widely described as a no-take area, technically it is not, as some recreational fishing is allowed.

\section{Increase in marine protected area coverage}

Year of marine protected area designation was used to calculate cumulative marine protected area over time since 1950. These data were available for c. $93 \%$ of marine protected areas, representing c. $98 \%$ of the total global coverage. Where inconsistencies between original year of designation and the area declared were known, this information was updated to reflect increases in coverage as accurately as possible. For example, the waters surrounding the Galapagos Islands were first protected in 1986 as a Marine Resource Reserve Area, and although there have been subsequent changes in designation type (Jones, 2013), in this analysis the area was considered protected from 1986 onwards. However, the no-take areas were zoned during 2000, and therefore those areas were considered as designated during that year.

In accordance with the methods of Wood et al. (2008) the remaining protected area (c. $2 \%$ of global coverage without information on year of designation) was distributed across all years from 1950 to 2013 according to the proportion of the total marine protected area designated in each year.

\section{Proposed marine protected areas}

Additional large marine protected areas have been proposed and may be designated in the next few years (Table 1). Online resources and communication with experts were used to estimate the likely size of these areas, many of which are proposed to cover entire Exclusive Economic Zones. The areas used in this research do not represent the final sizes of these marine protected areas, which are still in the consultation and planning stages, but rather a possible scenario for a future increase in marine protected area coverage. If designated, not all of the proposed marine protected areas will add to quantitative measures of global coverage, as some of these areas are already designated but with less strict protection levels than will be facilitated by the proposed designations. Thus before incorporating these areas into projections for possible future increases in marine protected area, the area already designated (up to the end of 2013) within each one's proposed limits was subtracted from the estimated area. The combined area of the proposed marine protected areas (Table 1) was distributed evenly across years from 2015 to 2020 to represent a hypothetical scenario for future marine protected area expansion. Linear regression of the logged hypothetical increase in cumulative global protected area from 2015 to 2020 (based on the proposed marine protected areas) was used to estimate a hypothetical annual growth rate.

Other possible future scenarios for increased marine protected area coverage were considered for the Sargasso Sea (Laffoley et al., 2011), the Arctic high seas and the global high seas (Sumaila et al., 2007, 2015), as well as a scenario treating the Southern Ocean area managed by the Commission for the Conservation of Antarctic Marine Living Resources as a marine protected area.

\section{Results}

\section{Global network of marine protected areas}

According to the Sea Around Us database 6,186 marine protected areas covering c. 11.9 million $\mathrm{km}^{2}$ were designated by the end of 2013. This represents 3.3\% of the world's oceans. Of that global protected area, $16 \%$ is within no-take areas, covering 1.93 million $\mathrm{km}^{2}$, or $0.53 \%$ of the global ocean. Of the ocean area within Exclusive Economic Zones 8\% (c. 11.3 million $\mathrm{km}^{2}$ ) is designated as protected. In the high seas c. 0.5 million $\mathrm{km}^{2}$ ( $0.2 \%$ of the high seas area) is protected.

The mean and median sizes of marine protected areas globally are c. 2,430 and $3.3 \mathrm{~km}^{2}$, respectively. The substantial difference between the two is attributable to the existence of a small number of very large marine protected areas, which dominate areal statistics. Whereas the smallest marine protected area covers a fraction of a hectare $(<0.001$ $\mathrm{km}^{2}$ ), the largest extends across $>1$ million $\mathrm{km}^{2}$.

Inclusion of the two $>1$ million $\mathrm{km}^{2}$ areas protected within Exclusive Economic Zones (in New Caledonia and the USA) during 2014 increases the total area of global ocean protected to c. 14.2 million $\mathrm{km}^{2}(3.9 \%)$ and almost $10 \%$ (c. 13.7 million $\mathrm{km}^{2}$ ) of the ocean that is within Exclusive Economic Zones. Given that other marine protected areas were established during 2014 it is likely that the true area of ocean protected is $>10 \%$ of the total within Exclusive Economic Zones.

The combined area of the 24 marine protected areas that are $>100,000 \mathrm{~km}^{2}$ (including those designated during 2014) is $>8.7$ million $\mathrm{km}^{2}$, representing $62 \%$ of global marine protected area. Thirteen of these were designated after 2006.

\section{Attainment of global coverage targets}

Cumulative global marine protected area increased steadily but slowly from the mid 1970s to 2006, apart from a few sharp increases when large areas were designated. This overall trend is similar to that described in Wood et al. (2008).

Almost all marine protected areas have been designated within Exclusive Economic Zones. A few have been declared in the high seas but they represent a small fraction of the total global marine protected area, only $4.4 \%$ (c. $530,000 \mathrm{~km}^{2}$ ). 
(a)

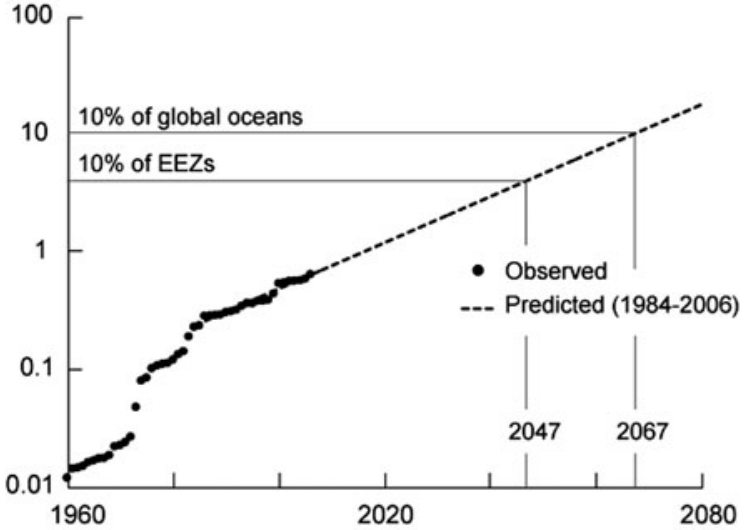

(c) 100

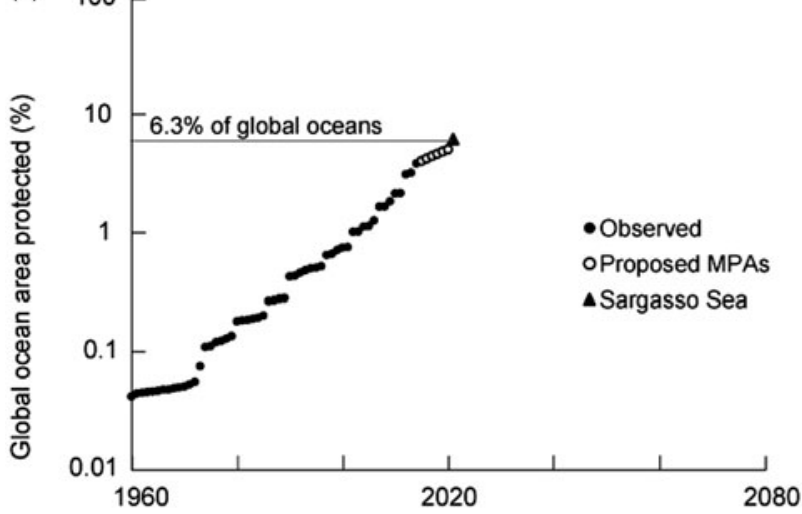

(b)

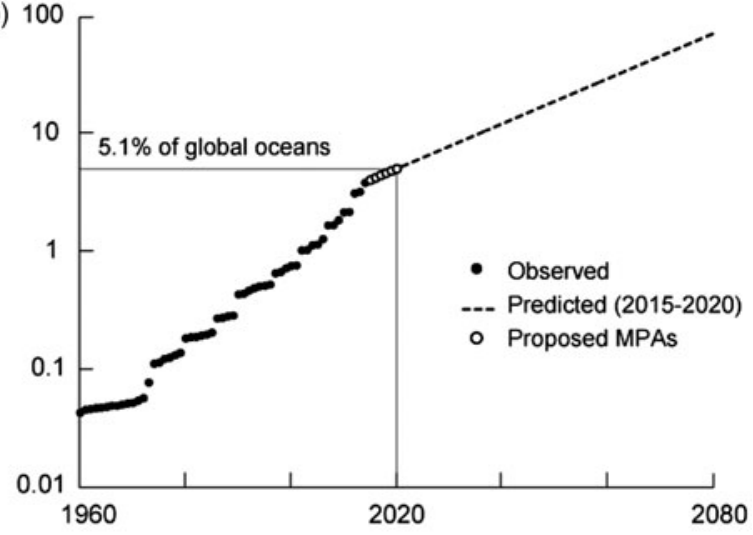

(d) 100

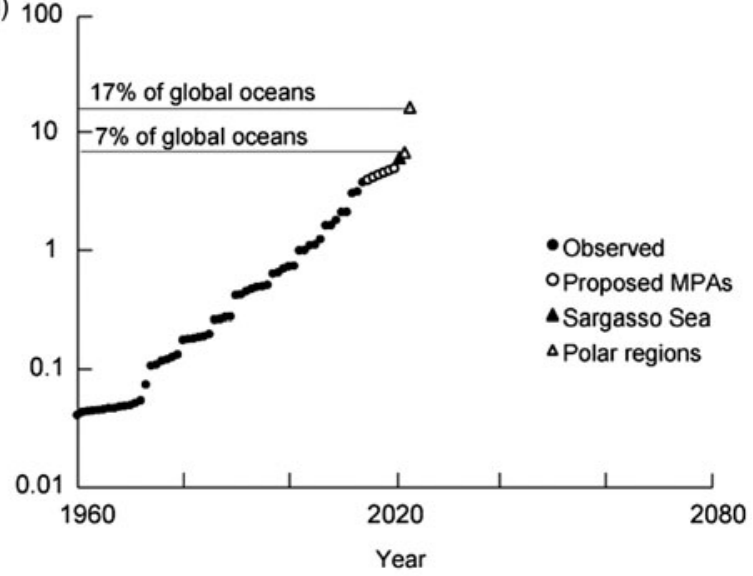

(e)

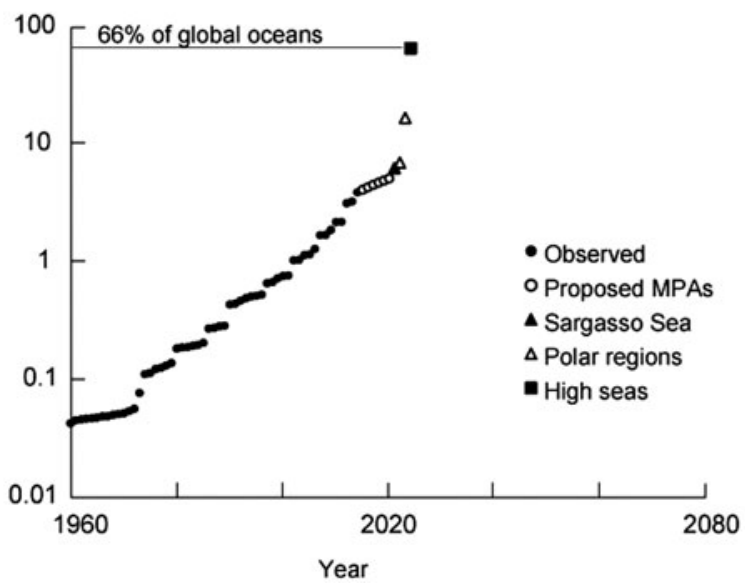

FIG. 1 Trends in the observed and projected global coverage of marine protected areas (MPAs). (a) Data from Wood et al. (2008), showing the observed (1960-2006) and projected increase $\left(4.6 \%, r^{2}=0.96\right.$; based on data for 1984-2006) of global marine protected area relative to the $10 \%$ targets. (b) Observed (1960-2014) and projected increases $\left(4.5 \%, r^{2}=0.99\right.$; based on a hypothetical increase for 2015-2020) of global marine protected area. Observed (1960-2014) increase of global marine protected area, including the addition of hypothetical marine protected areas in the Sargasso Sea (c), the High Arctic and the area of the Southern Ocean managed by the Commission for the Conservation of Antarctic Marine Living Resources (d), and the global high seas (e).

Thus, the annual rate of increase in cumulative protected area within Exclusive Economic Zones is virtually indistinguishable from the rate of increase of global marine protected area.

Fig. 1 shows the increase in the cumulative designated marine protected area since 1960 under various scenarios.
Fig. 1a shows the observed increase and a projection of the annual rate of increase in global marine area protected, based on data for $1984-2006\left(4.6 \%, r^{2}=0.96\right.$; Wood et al., 2008). Fig. $1 \mathrm{~b}$ shows the trend derived from data assembled for this study and a projection based on the proposed marine protected areas in Table $1\left(2015-2020 ; 4.5 \%, r^{2}=0.99\right)$. 
Figs $1 \mathrm{a}$ and $\mathrm{1b}$ exhibit different trends; the discrepancy is attributable primarily to the addition of several large U.S. marine protected areas to the current database. These were established prior to 2006 but had not previously been considered to be marine protected areas. As permanent fisheries management measures established with the primary aim of protecting natural heritage, their inclusion in a marine protected area database is debatable (Spalding et al., 2013).

Fig. $1 \mathrm{~b}$ also presents a possible scenario for a future increase in marine protected area coverage during 20152020, based on the proposed establishment of nine large marine protected areas within Exclusive Economic Zones (Table 1). If all of these marine protected areas were designated, protected area coverage within Exclusive Economic Zones would increase from 13.7 to 18.7 million $\mathrm{km}^{2}$, exceeding $10 \%$ coverage within areas under national jurisdiction and attaining protection of c. 5.1\% of global ocean. A regression calculated for this time period yields an estimate of $4.5 \%$ annual increase $\left(r^{2}=0.99\right)$. Figs $1 c-e$ show how the addition of hypothetical marine protected areas would influence such estimates of global marine protected area and progress towards the $10 \%$ target.

\section{Discussion}

The designation of a marine protected area is one step towards effective protection but it alone is insufficient for conservation outcomes. Nonetheless, designated marine protected area provides a simple metric that is communicable and quantifiable, and it has thus been chosen by the international community as an indicator of conservation progress.

Our results show an improvement in progress towards meeting the $10 \%$ coverage aspect of Aichi Target 11. Since the results of Wood et al. (2008) were presented, cumulative global marine protected area has increased fivefold, from 2.35 million $\mathrm{km}^{2}$ in 2006 to 11.9 million $\mathrm{km}^{2}$ in 2013 . During 2014 this increased to $>14.2$ million $\mathrm{km}^{2}$. This progress is attributable to the establishment of new marine protected areas (a few large sites in particular) and the inclusion of marine protected areas that were previously uncounted. Our results for total protected area for 2013 are similar to the cumulative coverage estimates of Spalding et al. (2013), which are based on data from the World Database of Protected Areas (ProtectedPlanet, 2015) up to 2012, although larger (11.9 vs 8.3 million $\mathrm{km}^{2}$ ) because of the inclusion of extensive Australian marine protected areas designated during November 2012 and the U.S. fisheries management areas already mentioned.

The results also suggest a concomitant increase in designated no-take area during the same time period, from $0.08 \%$ (Wood et al., 2008) to $0.53 \%$ of the global ocean in 2013. This no-take coverage represents approximately one-sixth of the area within marine protected areas (1.9 million $\left.\mathrm{km}^{2}\right)$ in 2014, approximately one-third of which comprises a single marine protected area, the Chagos Marine Reserve. Although this increase represents a likely improvement in no-take coverage, it is not known to what extent these marine protected areas are managed and enforced as no-take areas.

The increase in marine protected area coverage is largely a result of the establishment of a small number of large marine protected areas, which tend to dominate areal statistics. Additional large marine protected areas are proposed for designation in the coming years (Table 1). As of June 2015 the British government had allocated budget for the Pitcairn marine protected area. If designated, the proposed sites (Table 1), all located within Exclusive Economic Zones, would add c. 4.5 million $\mathrm{km}^{2}$ to the 14.2 million $\mathrm{km}^{2}$ already protected globally. Distributing this area evenly across years from 2015 to 2020 equates to a growth rate of c. $4.5 \%$ annually, which is similar to the rate of $4.6 \%$ calculated by Wood et al. (2008) for 1984-2006. The addition of the Pitcairn marine protected area to estimates of global no-take coverage would increase the area protected from extractive activities from 1.93 million $\mathrm{km}^{2}$ (in 2013) to 2.76 million $\mathrm{km}^{2}$.

Toonen et al. (2013) reported an annual rate of increase in marine protected area of $2.8 \%$ during $2006-2012$, which is significantly slower than the rates calculated here for proposed increase in marine protected areas during 20152020 and those calculated by Wood et al. (2008) for 19842006. Nonetheless, Toonen et al. (2013) predicted that protection of $10 \%$ of the global ocean could be achieved by 2025 . This is earlier than calculated here and discordant with the slower growth rate they reported.

Taking into account marine protected areas established since 2006 it is likely that $10 \%$ of areas under national jurisdiction are already protected. Yet protecting $10 \%$ of the global ocean remains out of reach. Assuming an annual growth rate of $4.5 \%$ could be maintained beyond 2020 (Fig. 1 b), the $10 \%$ global protection target would be reached c. 2035. Thus although recent expansion in marine protected area has drawn the date of attainment closer compared to the 2067 prediction of Wood et al. (2008), it is still unlikely to be realized before 2020. What is striking is the extent to which marine protected area needs to expand to accommodate such a target. Furthermore, how long the current growth rate can be sustained remains to be seen; we might expect to see a declining trend in the rate of marine protected area establishment as marine areas residual to extractive uses and not already protected become rarer (Mora \& Sale, 2011; Devillers et al., 2015). The hypothetical future scenarios presented in Figs $1 \mathrm{c}$ and $1 \mathrm{~d}$ suggest that vast areas of ocean will need to be protected to advance substantially towards $10 \%$ global coverage.

Up to mid 2014 the largest marine protected area established was the 1,070,000 $\mathrm{km}^{2}$ South Georgia and South Sandwich Islands marine protected area. Yet even with the 
establishment of a marine protected area in the Sargasso Sea, which could be almost four times that size, in addition to the nine proposed marine protected areas within Exclusive Economic Zones (Table 1) only 6.3\% of the global ocean would be protected. Adding the 2.5 million $\mathrm{km}^{2}$ Arctic high seas area would increase global coverage by only $0.7 \%$. However, adding the 35 million $\mathrm{km}^{2}$ Southern Ocean area managed by the Commission for the Conservation of Antarctic Marine Living Resources to calculations of global marine protected area coverage would expand global marine protected area to $>10 \%$, although the addition of large areas such as this would not contribute to ecological representativeness, one of the other aspects of Aichi Target 11. This area of the Southern Ocean is already designated an IUCN category IV protected area (Day et al., 2012), and therefore its inclusion in the global marine protected area network would not mean any changes to its management, or improved protection for the marine environment. Closing the high seas to fishing would protect c. $60 \%$ of the global ocean area (Fig. 1) and is predicted to yield environmental, economic and social benefits (Sumaila et al., 2015).

It is clear that the designation of a few large marine protected areas has had a significant impact on the quantitative extent of marine protected areas globally but concerns have been raised about potential negative implications of their designation over the longer term (e.g. Agardy et al., 2011; De Santo, 2013; OpenChannels, 2013). There is apprehension that they could amount to no more than paper parks, offering little, if any, protection in reality. Some scientists argue that the resource-limited nature of protected area implementation means we need to consider where the balance should fall between protection of remote, uncontested, intact areas and non-remote, exploited, imminently threatened locations, although this question has no immediate, science-based resolution. To others (Singleton \& Roberts, 2014; Wilhelm et al., 2014) it seems logical that all types of protection are necessary and we should not have to choose. Singleton \& Roberts (2014) argue that debate about the best type of marine protected area clouds the primary message that needs to reach the public and policy-makers: the ocean needs greater protection than it receives now. Despite differences in opinion, a key principle can be agreed upon: siting and design of protected areas should prioritize ecological goals over political ones (Craigie et al., 2014; McCauley et al., 2014).

Inevitably there are limitations to consider when interpreting the findings presented here. These limitations relate to the reliability of the data and the simplicity of marine protected area as a metric for biodiversity conservation. The quality of the global marine protected area dataset used here, and all large-scale protected area datasets, is influenced by the dynamic nature of protected areas (which are being designated and degazetted on an ongoing basis), ambiguity concerning inclusion and exclusion criteria, and the consistency and completeness of national and other data sources. It could be argued that some areas included in these calculations should have been excluded, and vice versa. The issue of what should be counted when quantifying marine protected area has been debated and there have been efforts by the IUCN to clarify the criteria (Dudley, 2008; Day et al., 2012; Eddy, 2013; Spalding et al., 2013). Aichi Target 11 also lacks a clear definition of 'other effective area-based conservation measures' (Woodley et al., 2012) in addition to protected areas. This term is open to interpretation; for these areas to contribute effectively to measures of conservation progress a definition needs to be developed that does not dilute the intentions of the target.

Regarding the second limitation, marine protected area coverage is a simplified indicator of conservation success, which tells us little, if anything, about conservation outcomes (Gaston et al., 2008). Coverage statistics hide shortcomings but also successes, such as heightened protection levels for marine protected areas that are already designated. At the Kermadec Islands, for example, a benthic protection area designated in 2007 covers the entire Exclusive Economic Zone but does not protect the water column (Eddy, 2013). There are plans to strengthen the level of protection to a notake area (Table 1; the area up to 12 nautical miles $(22 \mathrm{~km})$ from the coastline is already designated as no-take), although this would not affect estimates of global marine protected area coverage.

To understand and gauge fully the effectiveness of marine protected areas on a global scale we need to look beyond the number of square kilometres protected and provide an alternative metric for conservation success (Singleton \& Roberts, 2014). Developing and refining methods for assessing additional aspects of marine protected area implementation (protection level, management activities and conservation outcomes) will contribute to understanding global progress towards meeting international targets, but more importantly to understanding the role of marine protected areas in conserving biodiversity. As we make progress towards meeting the target of $10 \%$ coverage and look towards $30 \%$ no-take coverage these methods will provide a way to advance beyond quantitative goals and ensure the additional stipulations of Aichi Target 11 are met, so that what has been designated contributes to successful conservation outcomes.

\section{Acknowledgements}

This is a contribution of Sea Around Us, a scientific collaboration at the University of British Columbia funded by the Pew Charitable Trusts and the Paul G. Allen Family Foundation. We thank Clarissa Theriault and Ashley McCrea-Strub for their assistance in preparation of the data for this research, and Chris Hoornaert for his help with some spatial analyses. 


\section{References}

Agardy, T., Bridgewater, P., Crosby, M.P., Day, J., Dayton, P.K., Kenchington, R. et al. (2003) Dangerous targets? Unresolved issues and ideological clashes around marine protected areas. Aquatic Conservation: Marine and Freshwater Ecosystems, 13, 353-367.

Agardy, T., Di Sciara, G.N. \& Christie, P. (2011) Mind the gap: addressing the shortcomings of marine protected areas through large scale marine spatial planning. Marine Policy, 35, 226-232.

CBD (2010) COP 10 Decision X/2: The Strategic Plan for Biodiversity 2011-2020 and the Aichi Biodiversity Targets. United Nations Environment Programme, Nagoya, Japan.

Craigie, I.D., Pressey, R.L. \& Barnes, M. (2014) Remote regionsthe last places where conservation efforts should be intensified. A reply to McCauley et al. (2013). Biological Conservation, 172, 221-222.

Day, J., Dudley, N., Hockings, M., Holmes, G., Laffoley, D., Stolton, S. \& Wells, S. (2012) Guidelines for Applying the IUCN Protected Area Management Categories to Marine Protected Areas. IUCN, Gland, Switzerland.

De S Anto, E.M. (2013) Missing marine protected area (MPA) targets: how the push for quantity over quality undermines sustainability and social justice. Journal of Environmental Management, 124, 137-146.

DEFRA \& JNCC (2013) UK Biodiversity Indicators in your Pocket 2013. Department for Environment, Food and Rural Affairs (Defra) and the Joint Nature Conservation Committee (JNCC), London, UK.

Devillers, R., Pressey, R.L., Grech, A., Kittinger, J.N., Edgar, G. J., WARD, T. \& WAtson, R. (2015) Reinventing residual reserves in the sea: are we favouring ease of establishment over need for protection? Aquatic Conservation: Marine and Freshwater Ecosystems, 25, 480-504.

Dudley, N. (ed.) (2008) Guidelines for Applying Protected Area Management Categories. IUCN, Gland, Switzerland.

EDDY, T.D. (2013) On the need for meaningful marine protected area (MPA) standards. Aquatic Conservation: Marine and Freshwater Ecosystems, 23, 481-482.

Fitzsimons, J.A. (2011) Mislabeling marine protected areas and why it matters-a case study of Australia. Conservation Letters, 4, 340-345.

Gaston, K.J., Jackson, S.F., CANTÚ-SAlazar, L. \& CrUZ-Piñon, G. (2008) The ecological performance of protected areas. Annual Review of Ecology, Evolution, and Systematics, 39, 93-113.

Government of Bermuda (2013) Bermuda's Exclusive Economic Zone and its Future. Consultation Document. Ministry of Environment and Planning, Hamilton, Bermuda.

IUCN (2003) Recommendations of the Vth IUCN World Parks Congress, 5.22: Building a Global System of Marine and Coastal Protected Area Networks. IUCN, Gland, Switzerland.

IUCN (2014) A Strategy of Innovative Approaches and Recommendations to Enhance Implementation of Marine Conservation in the Next Decade, Submitted on 22 December 2014, Following the Deliberations of the IUCN World Parks Congress 2014. IUCN, Gland, Switzerland.

Jones, P.J.S. (2007) Point-of-View: Arguments for conventional fisheries management and against no-take marine protected areas: only half of the story? Reviews in Fish Biology and Fisheries, $17,31-43$.

Jones, P.J.S. (2013) A governance analysis of the Galápagos Marine Reserve. Marine Policy, 41, 65-71.

Kelleher, G. (1999) Guidelines for Marine Protected Areas. IUCN, Gland, Switzerland, and Cambridge, UK.

Laffoley, D., Roe, H.S.J., Angel, M.V., Ardron, J., Bates, N.R. Boy , I.L. et al. (2011) The Protection and Management of the Sargasso Sea: The Golden Floating Rainforest of the Atlantic Ocean.
Summary Science and Supporting Evidence Case. Sargasso Sea Alliance, Washington, DC, USA.

Marae Moana (2015) Http://www.maraemoana.gov.ck/ [accessed 6 August 2015].

Margules, C.R. \& Pressey, R.L. (2000) Systematic conservation planning. Nature, 405, 243-253.

Marianas Variety (2015) Palau joins Project Eyes on the Seas. Http://www.mvariety.com/regional-news/73337-

palau-joins-project-eyes-on-the-seas [accessed 6 August 2015].

McCauley, D.J., Young, H.S., Power, E.A., Bird, D.W., Durham, W.H., McInturfF, A. et al. (2014) Pushing back against paper-park pushers-reply to Craigie et al. Biological Conservation, 172, 223-224.

Mora, C. \& S ALE, P.F. (2011) Ongoing global biodiversity loss and the need to move beyond protected areas: a review of the technical and practical shortcomings of protected areas on land and sea. Marine Ecology Progress Series, 434, 251-266.

MPA News (2012) Cook Islands and New Caledonia Declare Intent to Designate Large Multi-use MPAs. Marine Affairs Research and Education (MARE), and Marine \& Environmental Affairs, University of Washington, Seattle, USA.

MPA News (2013) Australian Government Scraps Management Plans for New National System of Marine Reserves. Marine Affairs Research and Education (MARE), and Marine \& Environmental Affairs, University of Washington, Seattle, Washington.

MPA News (2014a) Australian Government Appoints Review Panels for Marine Reserves. Marine Affairs Research and Education (MARE), and Marine \& Environmental Affairs, University of Washington, Seattle, Washington.

MPA News (2014b) More Outcomes and Insights from IMPAC3. Marine Affairs Research and Education (MARE), and Marine \& Environmental Affairs, University of Washington, Seattle, Washington.

NOAa (National Oceanic And Atmospheric Administration) (2011) Definition and Classification System for U.S. Marine Protected Areas. Office of Ocean and Coastal Resource Management, NOAA Ocean Service, Silver Spring, USA.

NOAA (National Oceanic And Atmospheric Administration) (2013) Marine Protected Areas of the United States: Conserving Our Oceans, One Place at a Time. NOAA National Marine Protected Areas Center, Silve Spring, USA.

OpenChannels (2013) Large, meaningless MPAs divert attention from policies that could really make a difference. Https://www. openchannels.org/blog/message-bottle/large-meaningless-mpasdivert-attention-policies-could-really-make-difference [accessed 6 August 2015].

Protected Planet (2015) Http://www.protectedplanet.net [accessed 4 August 2015].

RSPB (The Royal Society for the Protection of Birds) (2014) An 'Ascension Island Ocean Sanctuary': An Initial Review of Options for Surveillance and Enforcement. RSPB, Sandy, UK.

Sea Around Us (2015) Http://www.seaaroundus.org/ [accessed 4 August 2015].

Singleton, R.L. \& Roberts, C.M. (2014) The contribution of very large marine protected areas to marine conservation: giant leaps or smoke and mirrors? Marine Pollution Bulletin, 87, 7-10.

Spalding, M.D., Meliane, I., Milam, A., Fitzgerald, C. \& Hale, L.Z. (2013) Protecting marine spaces: global targets and changing approaches. In Ocean Yearbook (eds A. Chircop, S. Coffen-Smout \& M. McConnell), pp. 213-248. Martinus Nijhoff Publishers, Ledien, The Netherlands.

Sumaila, U.R., Zeller, D., Watson, R., Alder, J. \& Pauly, D. (2007) Potential costs and benefits of marine reserves in the high seas. Marine Ecology Progress Series, 345, 305-310. 
Sumaila, U.R., Lam, V.W.Y., Miller, D.D., Teh, L., Watson, R.A. Zeller, D. et al. (2015) Winners and losers in a world where the high seas is closed to fishing. Scientific Reports, 5, 8481.

The Pew Charitable Trusts (2012) Overview: Global ocean legacy -Easter Island. Http://www.pewtrusts.org/en/imported-old/otherresources/2012/o6/11/overview-global-ocean-legacy-easter-island [accessed 6 August 2015].

The Pew Charitable Trusts (2015a) Global ocean legacy: Kermadec. Http://www.pewtrusts.org/en/projects/global-oceanlegacy-kermadec [accessed 6 August 2015].

The Pew Charitable Trusts (2015b) The Pitcairn Islands: The world's largest fully protected marine reserve. Http://www. pewtrusts.org/en/research-and-analysis/fact-sheets/2015/03/thepitcairn-islands [accessed 12 October 2015].

Toonen, R.J., Wilhelm, T., Maxwell, S.M., Wagner, D., Bowen, B.W., Sheppard, C.R. et al. (2013) One size does not fit all: the emerging frontier in large-scale marine conservation. Marine Pollution Bulletin, 77, 7-10.

Toropova, C., Meliane, I., Laffoley, D., Matthews, E. \& Spalding, M.D. (eds) (2010) Global Ocean Protection: Present Status and Future Possibilities. Agence des aires marines protégées, Brest, France; IUCN WCPA, Gland, Switzerland, Washington, DC \& New York, USA; UNEP-WCMC, Cambridge, UK; TNC, Arlington, USA; UNU, Tokyo, Japan; WCS, New York, USA.

Veitch, L., Dulvy, N.K., Koldewey, H., Lieberman, S., Pauly, D., Roberts, C.M. et al. (2012) Avoiding empty ocean commitments at Rio+20. Science, 336, 1383-1385.
Wilhelm, T.A., Sheppard, C.R.C., Sheppard, A.L.S., Gaymer, C.F., PARKS, J., WAGNER, D. \& LEWIS, N. (2014) Large marine protected areas-advantages and challenges of going big. Aquatic

Conservation: Marine and Freshwater Ecosystems, 24, 24-30.

WOOD, L.J. (2011) Global marine protection targets: how S.M.A.R.T. are they? Environmental Management, 47, 525-535.

Wood, L.J., Fish, L., Laughren, J. \& Pauly, D. (2008) Assessing progress towards global marine protection targets: shortfalls in information and action. Oryx, 42, 340-351.

Woodley, S., Bertzky, B., Crawhall, N., Dudley, N., Londoño, J.M., MacKinnon, K. et al. (2012) Meeting Aichi target 11: what does success look like for protected area systems? PARKS, 18, 23-36.

\section{Biographical sketches}

Lis A BOONZAIER manages a small team of communications specialists at the Save Our Seas Foundation. She is particularly interested in the intersection of media and science, and helping scientists to convey their findings to the public. Daniel PAULY is devoted to studying, documenting and promoting policies to mitigate the impact of fisheries on the world's marine ecosystems. The concepts, methods and software he (co-)developed are used throughout the world, in particular the Ecopath modelling approach and software (www.ecopath.org) and FishBase, the online encyclopedia of fishes (www.fishbase.org). 